\title{
Penguatan Pendidikan Karakter Berbasis Nilai- Nilai Kearifan Lokal di Sekolah
}

\author{
Daroe Iswatiningsih ${ }^{\mathrm{a}, 1}$, \\ a Universitas Muhammadiyah Malang, Jalan Raya Tlogomas 246, Malang, Indonesia, 65144 \\ ${ }^{1}$ iswatiningsihdaroe@gmail.com*
}

\begin{tabular}{ll}
\hline INFO ARTIKEL & ABSTRAK \\
\hline Sejarah Artikel: & Pendidikan karakter sampai saat ini masih perlu ditanamkan pada siswa \\
Diterima: 6-11-2019 & dalam pembelajaran. Pendidikan karakter diharapkan mampu \\
Direvisi: - & menguatkan lima nilai utama karakter, yakni nilai religius, nasionalis, \\
Disetujui: 18-11-2019 & mandiri, gotong royong, dan integritas. Dalam penguatan pendidikan \\
& karakter di sekolah dapat dilakukan melalui pendidikan budaya \\
\hline Kata Kunci: & berkearifan lokal. Budaya kearifan lokal perlu dikenalkan dan diajarkan di \\
kearifan lokal & sekolah agar menumbuhkan sikap cinta budaya. Para siswa saat ini \\
nilai & kurang memiliki sikap peduli dan mencintai budaya. Untuk itu, paparan \\
pendidikan karakter & berikut menjelaskan bagaimana mengimplementasikan pendidikan \\
penguatan karakter & karakter berbasis kearifan lokal.
\end{tabular}

\begin{tabular}{ll}
\hline & ABSTRACT \\
\hline Keywords: & Character education needs to be instilled in students in learning. Character \\
local wisdom & education is expected to be able to strengthen the five main values of \\
value & character, religious, nationalist, independent, mutual cooperation, and \\
character education & integrity. In strengthening character education in schools can be done \\
character building & through cultural education of local wisdom. Culture of local wisdom needs \\
& to be introduced and taught in schools to foster an attitude of loving \\
& culture. Students currently lack care and love for culture. For this reason, \\
& the following explanation explains how to implement character education \\
& based on local wisdom.
\end{tabular}

(C) Cultural Institute, University of Muhammadiyah Malang, Indonesia

\section{PENDAHULUAN}

Setiap hari masyarakat disuguhi oleh berita-berita yang membuat resah, prihatin dan cemas. Berita tentang kriminalitas seperti pencurian, perkelahian, hingga pembnuhan yang pelakunya kebanyakan berusia remaja. Perilaku lain para remaja yang tidak patut ditiru, seperti minum oplosan, pencabulan, narkoba, bullying, kekerasan atau tawuran antarkelompok. Mengapa mereka mudah melakukan hal ini? Dorongan apa yang menggerakkan mereka melakukan tindakan ini? Apakah mereka tidak berfikir masa depan? Menjawab pertanyaan ini tentunya melihat lingkungan yang sedang terjadi. Bahwa timbulnya berbagai fenomena ini dipicu oleh perkembangan teknologi dan informasi yang begitu cepat tanpa dipersiapkan dan disadari oleh masyarakat.

Perkembangan teknologi dan informasi menjadikan kita mudah untuk mengakses berbagai hal yang diperlukan dan mendukung kemudahan kehidupan manusia. Misalnya teknologi gadget yang sangat dikenal oleh remaja. Gadget merupkan suatu perangkat yang memiliki fungsi lebih spesifik bersifat praktis dan dirancang dengan teknologi canggih. Beberapa contoh perangkat yang masuk pada kategori gadget di antaranya adalah Laptop, MP3 Player, Netbook, E-Reader, Kamera, Xboox, 
Smartphone, Tablet dan masih banyak perangkat lain yang memiliki fungsi khusus dan berbeda-beda. Namun dari sekian macam gadget tersebut, ponsel, handphone atau smartphone yang banyak diminati masyakakat. Ponsel pada awalnya diciptakan untuk membatu berkomunikasi jarak jauh tanpa kabel yang bisa dengan mudah dibawa kemana saja.

Seiring perkembangan teknologi dan meningkatnya kebutuhan setiap individu maka terciptalah ponsel yang memiliki fungsi lebih dari sekedar perangkat komunikasi, belakangan ponsel jenis ini diberi nama smartphone. Smartphone memiliki kegunaan yang lebih bervariasi, selain fungsi utamanya sebagai alat komunikasi juga bisa digunakan untuk membaca artikel di website, membuka dokumen, bermain game, menonton video, dan masih banyak kegunaan lainnya yang bisa dilakukan oleh perangkat smartphone. Hal ini menjadikan remaja asyik dengan dunianya dan dirinya sendiri dengan mengabaikan lingkungan di sekitar. Ia fokus pada permainan game, menonton video, atau membuka akses lain di internet. Remaja menjadi kecanduan gadget yang bukan sebatas pada alat komunikasi semata. Menengarai persoalan atas fenomena perilaku remaja yang kurang baik di atas, berbagai penyebab dapat diidentifikasi akibat pengaruh gadget, lingkungan, ataukah pendidikan di sekolah yang kurang menumbuhkan karakter positip bagi anak. Untuk itu, pendidikan karakter perlu dikuatkan dalam upaya mencegah tumbuhnya karakter yang kurang baik bagi generasi muda, khususnya melalui pengenalan nilai-nilai budaya berkearifan lokal.

\section{PEMBAHASAN}

\section{Nilai-Nilai Kearifan Lokal}

Nilai merupakan suatu hal yang diyakini seseorang maupun kelompok dalam menggerakkan tindakan dan perilaku. Nilai yang tumbuh dalam masyarakat dan diterima dengan baik akan menjadi suatu pedoman dalam menjalani kehidupan bersama. Adisusilo (2012:56) mengartikan nilai sebagai sesuatu yang dipandang baik, bermanfaat, dan paling benar menurut keyakinan seseorang atau sekelompok orang. Karena nilai dianggap memberi manfaat dan dianggap baik, maka menjadikan nilai tersebut dihargai, dihayati dan diimplementasikan dalam kehidupan sehari-hari.

Nilai yang dihargai dan dijunjung tinggi oleh masyarakat akan mewarnai kehidupan masyarakat yang menjalaninya. Tentu saja hal ini menjadikan nilai bukan sekedar keyakinan, namun merupakan urat nadi dalam menjalani kehidupan. Nilai yang diyakini dan menjadi petunjuk bagi setiap orang selalu berkaitan dengan hal-hal yang positif, keluhuran budi, dan kebaikan. Untuk itu, Esteban (1990) menganggap nilai sangat dekat dengan moral. Menurutnya, nilai selalu berhubungan dengan kebaikan, kebajikan, dan keluhuran budi yang akan selalu dikejar oleh seseorang agar ia menjadi manusia yang sebenarnya; yakni manusia yang mampu memberi kebaikan pada orang lain.

Berbicara tentang nilai, maka setiap masyarakat memilikinya. Selanjutnya nilai ini akan mengatur sistem kehidupan berdasarkan sistem nilai yang diberlakukan. Keadaan inilah yang melahirkan kearifan lokal di setiap masyarakat yang memiliki sistem nilai yang berbeda. Setiap masyarakat memiliki kearifan lokal yang berbeda. Keraifan lokal dibangun dan ditumbuhkan dari pandangan hidup dan nilai-nilai yang menjadi pedoman masyarakat dalam menyelenggarakan kehidupannya. Oleh karena itu, kearifan lokal merupakan salah satu bentuk budaya. Kearifan lokal oleh Akhmar dan Syarifudin (2007) diartikan sebagai tata nilai atau perilaku hidup masyarakat lokal dalam berinteraksi dengan lingkungan tempat hidupnya secara arif bijaksana. Secara substantif kearifan lokal merupakan nilainilai yang berlaku dalam tatanan masyarakat, yang kebenarannya menjadi pedoman dalam bertingkah laku sehari-hari (way of life). Kearifan lokal biasanya 
diajarkan secara turun temurun dan diwariskan dari generasi ke generasi, dimulai dari kelauarga hingga di dalam masyarakat. Adapun kearifan lokal dapat diwujudkan dalam bentuk benda (tangible) dan tak benda (intangible), misalnya bahasa, sastra, kesenian, upacara, adat istiadat, keris, dan sebagainya.

Pengenalan terhadap kearifan lokal, seperti berupa benda keris berdasarkan nama, bentuk, fungsi, manfaat, serta maknanya sejak kecil yang ditumbuhkan dari keluarga akan menjadikan anak mengenal, memahami dan mencintai benda yang dimaksud. Demikian halnya pengenalan terhadap kesenian, tari misalnya. Dengan mengenalkan anak pada sebuah kesenian tari tertentu akan membangun karakternya. Hasil penelitian Iryanti (2017) menunjukkan bahwa siswa yang dikenalkan dan diajarkan terhadap sebuah kesenian tari, seperti Tari Manggala Yudha yang mengandung nilai filsafat nasionalis akan terbawa dalam kehidupannya. Menurut penciptanya Tari Maggala Yudha menggambarkan para pasukan perang yang sedang menjalankan perintah raja untuk berperang mempertahankan keraton. Gerakan terian sangat menggambarkan sikap sesuai karakter cerita, yakni tegas. Jadi karakter dalam Tari Manggala Yudha memiliki nilai-nilai seperti kepatriotan, tanggung jawab serta kewibawaan.

Kearifan lokal juga dapat berupa bahasa. Berbahasa bukan sebatas berkatakata untuk menyampaikan maksud dan pesan yang diwadahinya. Berbahasa juga mengandung maksud berinteraksi dan bersosialisasi antar individu, dengan kelompok dan masyarakat. Untuk itu, dalam berbahasa juga dimaksudkan untuk menjaga keharmonisan hubungan dalam bertetangga, dalam keluarga, dan sistem kemasyarakatan yang berlaku. Berbahasa yang santun adalah berbahasa yang menempatkan diri pada masing-masing kedudukannya, yang tidak menyinggung perasaan orang lain, serta yang menjadikan mitra bicara menjadi nyaman dan senang untuk melakukan sesuatu hal. Adapun berbahasa yang edukatif adalah tuturan yang mengandung nilai-nilai pendidikan, baik yang dimaksudkan oleh penutur maupun mitra tutur. Nilai-nilai pendidikan tersebut ditumbuhkan selama berlangsungnya komunikasi, baik dari aspek religi, sosial, moral, emosional, intelektual, dan kultural pada mitra tutur, khususnya dalam keluarga (Iswatiningsih, 2016).

Mengingat masyarakat Indonesia yang majemuk/ multikultural, maka pemahaman masyarakat terhadap kearifan lokal dalam menguatkan kebersamaan dan persatuan bangsa ini perlu dipahamkan, diwariskan, dan diajarkan dalam pendidikan, baik formal maupun informal. Keluarga, masyarakat, dan sekolah mampu menyosialisasikan serta menginternalisasikan kearifan lokal secara nyata melalui tindak berbahasa santun dan edukatif.

\section{Tujuan Melestarikan Kearifan Lokal}

Berdasarkan cakupan ruang lingkup kearifan lokal yang luas, maka tak mudah secara tegas menyebutkan tujuan melestarikan kearifan lokal. Namun demikian, secara umum kearifan lokal merupakan keberagaman produk budaya yang secara potensi perlu dilestarikan. Oleh karena itu, tujuan melestarikan kearifan lokal dapat dilihat dari kepentingan estetis, fungsional, ekonomi dan nilai produktif lainnya.

Tujuan melestarikan kearifan lokal dalam perspektif perencanaan dan perancangan kota (Respandi, 2009) dimaksudkan untuk (1) menjaga kelestarian kearifan lokal dengan menjaga norma adat dan tradisi budaya sebagai bagian dari peraturan perundangan, (2) proses perencanaan penataan lingkungan hunian dan kawasan produktif lainnya, (3) menetapkan kawasan pusaka budaya sebagai kawasan strategis untuk kepentingan sosialbudaya sesuai dengan kriteria yang ditetapkan, dan (4) mendorong berkembangnya kegiatan yang dapat menunjang karakter dan kualitas kawasan pusaka. 
Pengelompokan kearifan lokal berdasarkan jenisnya, dibedakan menjadi lima kategori, yakni (a) makanan, (b) pengobatana (c), teknik produksi, (d) industri rumah tangga, dan (e) pakaian. Untuk itu, tujuan melestarikan kearifan lokal pada kategori iniadalah mengembangkan dan mendayagunakan untuk kepentingan masyarakat. Dalam lingkup budaya, dimensi fisik dari kearifan lokal lebih komprehensif, yakni meliputi aspek: (1) upacara adat, (2) cagar budaya, (3) pariwisata alam, (4) transportasi tradisional, (5) permainan tradisional, (6) prasarana budaya, (7) pakaian adat, (8) warisan budaya, (9) museum, (10) lembaga budaya, (11) kesenian, (12) desa budaya, (13) kesenian dan kerajinan, (14) cerita rakyat, (15) dolanan anak, dan (16) wayang (Wagiran, 2012). Untuk itu, tujuan melestarikan kearifan lokal adalah upaya menjaga, melestarikan, dan mengembangkan aspekaspek rincian budaya tersebut. Tujuan secara hakiki dari upaya pelestarian budaya kearifan lokal adalah memberikan nilai pendidikan dan pegetahuan pada generasi selanjutnya. Selain itu, juga mendukung nilai kebudayaan dan pariwisata apabila dapat mengelola dan mempromosikan dengan baik.

Beberapa kearifan lokal yang sampai saat ini masih dipertahankan di masingmasing masyarakat adalah bercocok tanam/ bertani secara tradisional. Di beberapa wilayah pedesaan, masyarakat yang masih berprofesi sebagai etani akan melakukan tradisi saat akan memulai bercocok tanam. Mereka berharap untuk keselamatan dan hasil padi yang melimpah (Novella, 2018). Para petani di Desa Lambeyan Wetan, Kecamatan Lambeyan, Kabupaten Magetan tersebut melakukan serangkaian tahapan acara demi untuk memuji pada Tuhan Sang Pencipta Alam. Jika sebelumnya, ritual yang dilakukan tersebut ditujukan ada Dewi Sri, saat ini mengalami pergeseran keyakinan, yakni hanya kepada Tuhan. Demikian halnya ritual atau tradisi-tradisi lain yang masih berlangsung di masyarakat untuk dijalani. Semua ini merupakan kearifan lokal yang penting dilestarikan karena di dalamnya tentu memuat nilai-nilai karakter.

\section{Pendidikan Karakter}

Karakter menurut Kamus Bahasa Indonesia (2008) merupakan sifat-sifat kejiwaan, akhlak atau budi pekerti yang membedakan seseorang dengan orang lain. Samani (2014) menyatakan bahwa karakter dapat dimaknai sebagai cara berpikir dan berperilaku yang khas pada setiap individu untuk hidup dan bekerja sama, baik dalam lingkungan keluarga, masyarakat, bangsa dan negara. Seorang yang berkarakter baik, maka ia mampu membuat keputusan dan siap mempertanggungjawabkannya. Karakter senantiasa dikaitkan dengan perilaku seseorang dalam hubungannya dengan Tuhan, diri sendiri, sesama, lingkungan, kebangsaan yang terwujud dalam pikiran, perasaan, perkataan, dan perbuatan menurut norma yang berlaku. Dengan demikian, karakter merupakan representasi dari nilai-nilai baik seseorang yang ditampilkan dalam perilaku atau sikap sehari-hari, dengan siapa, dimana dan dalam kegiatan apa.

Karakter menurut Lickona (1991:22) adalah sifat alami seseorang dalam merespon situasi secara bermoral. Pendidikan karakter menurut Lickona adalah pendidikan untuk membentuk kepribadian seseorang melalui pendidikan budi pekerti, yang hasilnya terlihat dalam tidakan nyata seseorang, yaitu tingkah laku yang baik, jujur, bertanggung jawab, menghormati hak orang lain, kerja keras dan sebagainya.

Karakter seseorang ditumbuhkan, ditanamkan dan dikuatkan dalam waktu yang cukup lama. Untuk itu, pendidikan karakter umumnya dimulai dalam keluarga. Keluarga merupakan fondasi utama dalam membangun karakter anak (Lestari, 2013). Namun apa yang terjadi saat ini, banyak keluarga yang mengalihkan perannya kepada asisten rumah tangga atau pengasuh anak dan lembaga pendidikan karena tututan pekerjaan. Orang tua tidak mampu sepenuhnya melaksanakan perannya 
mendidik anak. Akibat perubahan zaman ini, mau tidak mau sekolah berupaya untuk mewujudkan harapan orag tua dan masyarakat sebagai lembaga pendidikan yang membentuk anak tidak hanya cerdas namun juga berkarakter.

Karakter pada dasarnya ditumbuhkan, dikembangkan dan diinternalisasikan dengan sengaja dan sungguh-sungguh dimulai dari keluarga, berlanjut di masyarakat dan sekolah. Keluarga merupakan unit terkecil dalam masyarakat yang mendasari pembentukan karakter anak. Namun apa yang dapat kita lihat dalam keluarga-keluarga di ligkungan kita. Berbeda dengan keluarga pada masa dulu, dimana orang tua mencurahkan waktu dan perhatiannya hanya untuk keluarga. Ayah menghabiska waktu bekerja di luar rumah dan ibu mencurahkan segenap jiwa raga untuk memperhatikan tumbuh kembang anak. Orang tua mengenalkan dan mempraktikkan nilai-nilai kebajikan dalam berbagai kesempatan melalui cerita, petuah, teladan, dan kebiasaan sehari-hari. Waktu anak banyak dihabiskan di lingkungan rumah - bermain dengan sebaya - serta dengan keluarga.

Zaman telah berubah, keluarga pun mengalami perubahan mendasar. Tuntutan ekonomi, menjadikan orang tua memiliki sedikit waktu dengan anak. Para orang tua kadang membuat alasan bahwa quality time dengan anggota keluarga lebih penting. Kadang waktu khusus bersama keluarga hanya di hari libur saja. Dengan tuntutan kebutuhan hidup pula menjadikan orang tua tidak hidup satu atap. Mereka berpisah sementara, semata-mata hanya demi pekerjaan yang menuntutnya. Tentu hal ini akan berdampak pada pendidikan karakter anak dalam keluarga. Terlebih lagi apabila orang tua kurang memahami peran dan fungsi terhadap pendidikan karakter anak. Sekolah dan guru dianggap orang yang berkompeten dan bertanggung jawab terhadap pendidikan anak. Oleh karena itu, penting sekali menyadarkan dan memahamkan orang tua dalam pegasuhan dan penguatan pendidikan karakter. Terlebih lagi mengingat perkembangan teknologi informasi semakin pesat saat ini.

Sekolah sebagai wadah dalam penguatan pendidikan karakter sudah tepat. Sebagai lembaga formal, tentu sekolah memiliki rancangan sistem pembelajaran yang menguatkan kompetensi kofnitif, afektif, dan psikomotorik. Aspek yang penting dikuatkan dalam pembelajaran kita saat ini adalah memumbuhkan dan menguatakan karakter peserta didik. Hal ini juga terjadi pada beberapa negara lain yang membangun karakter melalui pembiasaan, aktivitas bebrsama teman serta belajar di kelas. Lickona (2013) memaparan dengan terinci dan jelas pentingnya karakter bagi anak, keluarga serta sistem yag dibangun dalam sekolah. Secara luas dan teknis, Lickona menjelaskan materi atau konten karakter yang penting dikembangkan di sekolah dan keluarga. Tentu saja dibutuhkan kesungguhan dan pendampingan yang terus menerus kepada anak dalam menguatkan pendidikan karakter agar benar-benar terinternalisasikan dalam kehidupan seharihari.

\section{Tujuan Penguatan Pendidikan Karakter}

Dalam upaya menjawab berbagai persoalan yang muncul, tantangan, tuntutan serta orientasi pendidikan dan pembelajaran, maka perlu dilakukan penataan kembali atau transformasi pendidikan dengan mendasarkan pada karakter. Hal ini dimaksudkan guna memberikan kebermaknaan hidup bagi peserta didik, tenaga pendidik, serta stakeholder yang terkait dengan kependidikan. Untuk itu, penguatan pendidikan karakter ini dicanangkan sebagai sebuah program dalam meningkatkan kompetensi siswa dan tenaga kependidikan abad 21 dalam menjawab berbagai kebutuhan. Untuk itu, tujuan PPK adalah:

(1) Mengembangkan platform pendidikan nasional yang meletakkan makna dan nilai karakter sebagai jiwa atau generator utama penyelenggaraan pendidikan. 
(2) Membangun dan membekali Generasi Emas Indonesia 2045 menghadapi dinamika perubahan di masa depan dengan keterampilan abad 21.

(3) Mengembalikan pendidikan karakter sebagai ruh dan fondasi pendidikan melalui harmonisasi olah hati (etik dan spiritual), olah rasa (estetik), olah pikir (literasi dan numerasi), dan olah raga (kinestetik).

(4) Merevitalisasi dan memperkuat kapasitas ekosistem pendidikan (kepala sekolah, guru, siswa, pengawas, dan komite sekolah) untuk mendukung perluasan implementasi pendidikan karakter.

(5) Membangun jejaring pelibatan masyarakat (publik) sebagai sumbersumber belajar di dalam dan di luar sekolah.

(6) Melestarikan kebudayaan dan jati diri bangsa Indonesia dalam mendukung Gerakan Nasional Revolusi Mental (GNRM)

Dari keenam tujuan Penguatan Pendidikan Karakter tersebut, melestarikan kebudayaan turut menentukan dalam memperkuat karakter remaja dan generasi muda. Kebudayaan yang merepresentasikan nilai-nilai kearifan lokal merupakan salah satu aspek penting untuk ditumbuhkan dan dilestarikan guna membangun generasi yang berkarakter dan mencirikan jati diri bangsa. Sebuah bangsa tentu harus dibangun dari individu-individu yang memiliki personality yang bagus. Hal ini sebagaimana hasil penelitian Fajarini (2014), terdapat dua indikator yang menunjukkan seseorang berkarakter. Pertama, dari aspek bertingkah laku. Bagaimana seseorang bertingkah laku dalam kesehariannya, apakah ia menunjukkan berperilaku tidak jujur, kejam dan rakus? Tentulah orang tersebut memanifestasikan dengan perilaku yang buruk, yang secara normatif tidak berlaku di dalam masyarakat. Sebaliknya, apabila seseorang berperilaku jujur, suka menolong, tentulah orang tersebut memanifestasikan karakter mulia. Kedua, dari aspek personality. Yang menentukan seseorang berkarakter dapat dilihat dari personality, yaki hal-hal yang melekat pada dirinya. Seseorang baru bisa disebut 'orang yang berkarakter' (a person of character) apabila tingkah lakunya sesuai kaidah moral.

Sikap karakter yang diharapkan dimiliki oleh masyarakat Indonesia meliputi cinta kepada Allah dan melaksanakan ajarannya, bertanggung jawab, sikap disiplin, mandiri, jujur, hormat dan santun, kasih sayang, peduli dan kerja sama, bekerja keras dan pantang menyerah, percaya diri, kreatif dan inovatif, bersikap adil dan bijaksana, rendah hati, toleransi, cinta damai dan persatuan. Saat ini beberapa sikap karakter disederhanakan menjadi lima aspek, yakni karakter religius, nasionalis, percaya diri, mandiri, dan integritas. Adapaun Character Counts di Amerika meliputi karakter: dapat dipercaya, rasa hormat dan perhatian, tanggung jawab, jujur, peduli, nasionalis, ketulusan, berani, tekun, dan integritas. Karakter kuat yang melekat pada sebagian besar masyarakat Indonesia sampai saat ini adalah 'gotong royong', 'musyawarah untuk mufakat', 'sikap toleransi', dan 'sopan santun'.

\section{Prinsip Pendidikan Karakter}

Pendidikan karakter di sekolah akan terlaksana dengan lancar, jika guru dalam pelaksanaannya memperhatikan beberapa prinsip pendidikan karakter. Kemendiknas memberikan rekomendasi 11 prinsip untuk mewujudkan pendidikan karakter sebagai berikut.

a. Mempromosikan nilai-nilai dasar etika sebagai basis karakter

b. Mengidentifikasi karakter secara komprehensif supaya mencakup pemikiran, perasaan dan perilaku.

c. Menggunakan pendekatan yang tajam, proaktif dan efektif untuk membangun karakter

d. Menciptakan komunitas sekolah yang memiliki kepedulian

e. Memberi kesempatan kepada peserta didik untuk menunjukkan perilaku yang baik 
f. Memiliki cakupan terhadap kurikulum yang bermakna dan menantang yang menghargai semua peserta didik, membangun karakter dan membantu mereka untuk sukses.

g. Mengusahakan tumbuhnya motivasi diri pada para peserta didik

h. Menfungsikan seluruh staf sekolah sebagai komunitas moral yang berbagi tanggung jawab untuk pendidikan karakter dan setia pada nilai dasar yang sama

i. Adanya pembagian kepemimpinan moral dan dukungan luas dalam membangun inisiatif pendidikan karakter

j. Menfungsikan keluarga dan anggota masyarakat sebagai mitra dalam usaha membangun karakter

k. Mengevaluasi karakter sekolah, fungsi staf sekolah sebagai guru karakter dan manifestasi karakter positif dalam kehidupan peserta didik.

Dari kesebelas prinsip mewujudkan sikap berkarakter siswa di sekolah dapat dikeleompokkan menjadi lima hal utama, yakni adanya sikap keteladanan pihak sekolah; sistem dan kebijakan yang diberlakukan oleh sekolah yang meliputi (a) memberi kesempatan dan kepercayaan pada siswa serta memotivasi dan (b) evaluasi yang efektif; menjalin kemitraan dengan keluarga dalam menguatkan pendidikan karakter anak. Apabila sekolah dan keluarga bersinergis dalam menguatkan pendidikan karakter anak, memotivasi, memberikan kepercayaan, dan senantiasa mengevaluasi perkembangan karakter anak tentu penguatan pendidikan karakter iniakan berjalan efektif.

\section{Implementasi Pendidikan Karakter Berbasis Kearifan Lokal \\ Di Kelas}

Pendidikan karakter yang ditanamkan guru saat berlangsung pembelajaran di kelas berbasis kearifan lokal dapat dilakukan guru dengan menyusun rencana pelaksanaan pembelajaran (RPP) yang memperhatikan kearifan lokal. Misalnya pada pembelajaran Bahasa indonesia di SD dengan kompetensi Dasar "Memahami kedudukan, fungsi, dan ragam bahasa Indonesia", maka guru dapat membuat apersepsi tentang keragaman bahasa daerah di Indonesia, menunjukkan bentukbentuk pengucapan angka 1-10 denga menggunakan berbagai daerah. Siswa diminta mengulangi secara bersama-sama. Dalam pelaksanaan pembelajaran inti, guru juga dapat membuat materi dengan mencontohkan macam-macam bahasa daerah di Indonesia dan meminta siswa memeragakan percakapan dari masingmasing daerah yang berbeda bahasa.

Demikian halnya pada pembelajaran PKn, misalnya pada tema "Kemajemukan", maka guru dapat menyiapkan materi berbasis kearifan lokal masyarakat Indonesia yang berbeda-beda suku, agama, bahasa, pendidikan, pekerjaan, status sosial, dan sebagainya demi menumbuhkan kesadaran kepada peserta didik adanya perbedaan. Selanjutnya hal dengan mengetahui perbedaan, guru berupaya untuk membangun kesatuan dan persatuan bangsa.

Dari contoh di atas, pendidikan karakter yang dikembangkan dalam pembelajaran di kelas adalah karakter nasionalis, kerja sama, dan integritas (pernyataan dan tindakan sesuai)

Contoh lain pada pembelajaran IPS di SMP dengan KD berikut.

3.1 Memahami konsep ruang (lokasi, distribusi, potensi, iklim, bentuk muka bumi, geologis, flora, dan fauna) dan interaksi antarruang di Indonesia serta pengaruhnya terhadap kehidupan manusia dalam aspek ekonomi, sosial, budaya, dan pendidikan.

4.1 Menjelaskan konsep ruang (lokasi, distribusi, potensi, iklim, bentuk muka bumi, geologis, flora dan fauna) dan interaksi antarruang di Indonesia serta pengaruhnya terhadap kehidupan manusia Indonesia dalam 
aspek ekonomi, sosial, budaya, dan pendidikan.

\section{Di Sekolah}

Di sekolah perlu diciptakakan budaya sekolah yang mampu menguatkan karakter baik/ positif pada peserta didik. Dalam buku Panduann PPK bagi Guru (Kemdikbud, 2017) dipaparkan bahwa kegiatan yang dapat dikembangkan dalam membangun budaya sekolah adalah 1) pembiasaan dalam kegiatan literasi; 2) kegiatan ekstrakurikuler, yang mengintegrasikan nilai-nilai utama PPK, dan 3) menetapkan dan mengevaluasi tata tertib atau peraturan sekolah. Budaya sekolah yang baik dapat mengembangkan iklim akademik yang kompetitif dan kolaboratif, yang diperlukan sekolah dalam menetapkan atau memperkuat branding sekolah.

Dalam upaya mengimplementasikan penguatan pendidikan karakter berbasis budaya sekolah melalui pembiasaan dalam kegiatan berliterasi, guru atau sekolah dapat memanfaatkan kearifan lokal dari berbagai budaya yang ada di Indonesia sebagai sumber literasi. Dengan demikian, siswa menjadi mengenal, memahami dan yang memiliki nilai-nilai luhur yang akan ditampilkan dalam sikap dan perilaku sehari-hari.

Pendidikan karakter berbasis budaya di sekolah misalnya kegiatan yang dilakukan Unit Kegiatan Siswa (UKS) seperti yang diselenggarakan oleh berbagai satuan pendidikan formal dan nonformal pada dasarnya sudah bermuatan pedidikan karakter yang dapat dikembangkan pada peserta didik. Contoh: unit kegiatan bela diri (Pencak Silat), apabila dihayati dan benarbenar ditujukan untuk pengembangan pendidikan karakter peserta didik, dapat diarahkan untuk memperkuat atribut komitmen, bersemangat, mandiri, dan tangguh. Kegiatan pelatihan harus terprogram dengan baik, ada durasi, capaian, dan keberlanjutan. Pelatihan seharusnya diarahkan pada transformasi keyakinan, motivasi, karakter, impian, sampai akhirnya dalam durasi tertentu terjadi transformasi diri berkarakter yang seutuhnya.

Pada dasarnya ada lima prinsip transformasi yaitu: (1) meyakini dan mendayagunakan kekuatan dan anugerah Tuhan dalam diri; (2) membuat pilihan dan keputusan dalam diri; (3) melakukan kebiasaan-kebiasaan baik secara terus menerus dalam kehidupan ini; 4) mampu membangun interaksi dengan orang lain; (5) mampu bekerja secara sinergis dan kreatif dengan orang lain dalam organisasi. Dalam pelaksanaan pelatihan harus diperhitungkan efisiensi dan efektivitasnya.

\section{Di Masyarakat}

Penguatan pendidikan karakter berbasis kearifan lokal yang bekerja sama dengan komunitas, misalnya mendatangkan kesenian tari topeng Malangan. Komunitas ini beratraksi di sekolah. Dengan melihat langsung para pelaku seni dalam mempersiapkan hingga pelaksanaan kegiatan, seperti alat musik, kostum dan aksesoris yang dipakai, media topeng serta gerakan yang ditampilkan akan membuat peserta didik terpesona. Mereka akan turut menjiwai karena merasa dekat dan tahu persis kesenian tari di sekolahnya.

Contoh lain penguatan karakter berbasis kearifan lokal adalah program Siswa Bakti Desa, sebagaimana yang dilakukan oleh SMAN 3 Malang bagi siswa kelas $X$. Mereka datang ke masyarakat di sebuah desa dan menginap di rumah-rumah warga selama 3 hari. Selama itu peserta didik bergaul dekat degan masyarakat. Mereka membantu mengolah makanan, membersihkan rumah dan halaman, juga berakivitas bersama teman dan warga desa seperti kerja bakti. Mereka merasakan kebersamaan itu dan telah berbuat sesuatu untuk masyarakat. Kegiatan lain yang para siswa lakukan sesuai dengan program yang telah direncanakan.

Pendidikan karakter yang dapat dikembangkan pada kedua contoh di atas adalah mencintai budaya setempat, kerja sama (gotong royong), menumbuhkan 
kepedulian (empati), tanggung jawab, mandiri, religius, dan disiplin.

\section{PENUTUP}

Penguatan pendidikan karakter berbasis kearifan lokal penting dilakukan saat ini. Hal ini sebagai upaya bangsa Indonsia dalam melestarikan budaya lokal yang ada. Budaya lokal di masing-masing wilayah sangat beragam dan banyak. Jika tidak kita lestarikan dan kembangkan dikhawatirkan akan punah atau diakui dan diambil oleh bangsa lain. Salah satu upaya melestarikan budaya berkearifan lokal dengan meguatkan pendidikan karakter peserta didik dan bangsa melalui penguatan pendidikan karakter nasionalis, religius, gotong royong, mandiri, dan integritas dan menginternalisasikan dalam sikap dan perilaku hidup sehari-hari.

\section{REFERENSI}

Adisusilo, S. (2012). Pembelajaran Nilai karakter. Jakarta: Rajawali Pers.

Akhmar, A. M., \& Syarifuddin. (2007). Mengungkap Kearifan Lingkungan Sulawesi Selatan. PPLH Regional Sulawesi, Maluku dan Papua, Kementerian Negara Lingkungan Hidup RI dan Masagena Press, Makasar

Esteban, E. J. (1990). Education in Values: what, why, and for whom. Manila: Sinag-tala Publisher, Inc.

Fajarini, U. (2014). Peranan Kearifan Lokal Dalam Pendidikan Karakter. Sosio Didaktika: Vol. 1, No. 2 Des 2014.

Iryanti, I. (2017). Kajian Tentang NilaiNilai Kearifan Lokal Yang Dikembangkan Sanggar Seni Sekar Pandan Untuk Menumbuhkan Nasionalisme. Jurnal Pendidikan Kewaraganegaraan dan Hukum, FISUNY.
Iswatiningsih, D. (2016). Tindak Tutur Berdimensi Edukatif dalam Komunikasi Keluarga. Disertasi, Universitas Negeri Malang. Laman. http://karya-

ilmiah.um.ac.id/index.php/disertasi/artic le/view/52714

Julaiha, S. (2014). Implementasi Pendidikan Karakter dalam Pembelajaran. Dinamika Ilmu, Vol. 14. No 2, Desember.

Kementerian Pendidikan dan Kebudayaan. (2017). Modul Pelatihan Penguatan Pendidikan Karakter bagi Guru.

Kementerian Pendidikan dan Kebudayaan. (2017). Modul Pelatihan Penguatan Pendidikan Karakter bagi Kepala Sekolah.

Kementerian Pendidikan dan Kebudayaan. (2017). Modul Pelatihan Penguatan Pendidikan Karakter bagi Komite.

Lestari, Sri. 2013. Psikologi Keluarga. Jakarta: Kencana Prenada Media Group

Lickona, T. (1991). Educating For Character: How Our School Can Teach Respect and Rresponsibility. New York: Bantam Book.

Lickona, T. (2013). Character Matters: Persoalan Karakter. Jakarta: Bumi Aksara.

Novella, Y. W. (2018). "Upacara Menanam Padi Di Desa Lembeyan Wetan, Kecamatan Lembeyan, Kabupaten Magetan". Haluan Sastra Budaya, Volume 2, No. 1 Juni 2018.

Samani, M., \& Hariyanto. (2014). Konsep dan Model Pendidikan Karakter. Bandung: Remaja Rosdakarya.

Suhartono, S. (2007). Filsafat Pendidikan. Yogyakarta: Ar-Ruzz Media. 
Wagiran. (2012). Pengembangan Karakter Berbasis Kearifan Lokal. Hamemayu Hayuning Bawana: Identifikasi Nilainilai Karakter Berbasis Budaya. Jurnal Pendidikan Karakter, Tahun II, No.3, Oktober 2012.

Wikantiyoso, R., \& Tutuko, p (Ed.). (2009). Kearifan Lokal: Dalam Perencanaan dan Perancangan Kota. Malang: Group Konservasi Arsitektur \& Kota. 